\title{
$\begin{array}{ll}\text { Research Square } & \text { Preprints are preliminary reports that have not undergone peer review. }\end{array}$ or referenced by the media as validated information. \\ Effect of Various Potential Additives on Hydrogen Fermentation During the Co-Digestion of Food Waste and Cow Dung
}

\section{Chinmay Deheri}

Siksha O Anusandhan University Institute of Technical Education and Research

Saroj Kumar Acharya ( $\nabla$ saroj.acharya76@gmail.com )

Siksha O Anusandhan University

\section{Research}

Keywords: Anaerobic co-digestion, Hydrogen, Calcium peroxide, Zinc oxide, Copper oxide, Calcium carbonate

Posted Date: September 25th, 2020

DOl: https://doi.org/10.21203/rs.3.rs-81013/v1

License: (c) (i) This work is licensed under a Creative Commons Attribution 4.0 International License. Read Full License 


\section{Abstract}

The effect of calcium peroxide $\left(\mathrm{CaO}_{2}\right)$, zinc oxide $(\mathrm{ZnO})$, copper oxide ( $\left.\mathrm{CuO}\right)$, and calcium carbonate $\left(\mathrm{CaCO}_{3}\right)$ as additives during the anaerobic co-digestion of food waste and cow dung is experimentally investigated to enhance the hydrogen fermentation. The maximum concentration of hydrogen in the generated gas is found to be $26.43 \%, 21.67 \%, 17.64 \%$, and $20.84 \%$ while the cumulative yield of hydrogen remains 114.1, 109.27, 104.87, and $107.38 \mathrm{~mL} \mathrm{~g}^{-1}$ Total Solid (TS) with $\mathrm{CaO}_{2}, \mathrm{ZnO}$, CuO, and $\mathrm{CaCO}_{3}$ respectively. The sample in which no additive is used (control) exhibits a maximum hydrogen concentration of $17 \%$ and a cumulative hydrogen generation of $101.57 \mathrm{~mL} \mathrm{~g}^{-1}$ TS in the produced gas. Result reveals an enhancement in the hydrogen concentration up to $9.43 \%$ whereas the cumulative hydrogen yield is increased up to $11 \%$ with additives compared to the control sample. Overall the hydrogen fermentation can be significantly enhanced with the additives through the anaerobic codigestion process.

\section{Introduction}

Food waste is generated at various stages of production, refining, processing, distribution, and consumption. The accumulation of food wastes at all stages is very huge and transforms into a global problem. Various surveys and analyses show that the amount of global loss of food and food wastes is one-third and half of all the food produced from different sources [1]. In the developing countries, most of the food waste is generated at the production stage due to lack of updated technologies whereas in developed countries the losses occur at the consumption stage. The data reflects that in developed countries about $100 \mathrm{~kg}$ per person per year of food is wasted at the consumption stage [1]. The accumulation of food waste generates various problems and creates many diseases along with the emissions of harmful gases. The problem of disposal makes it compulsory to find ways of reduction. The ancient methods of disposal like landfill and incineration are not so useful because of land availability and high energy consumption [2]. So, an effective method needs to be introduced which can solve the problems related to food waste. The various ways and methodologies have come up from the research fraternity and suggest that energy can be extracted from the food waste.

The effective conversion of food waste into energy might be a blessing to society rather than a problem. Biogas and Hydrogen generation is the best alternative that can be generated from food waste. Performances of biogas and hydrogen on a diesel engine in dual fuel mode were found to have a significant effect on reducing the emission for a clean and green environment [3]. Hydrogen serves as the most promising and very important carrier of energy which could play a magnificent role in greenhouse gas emissions [4]. Various mechanisms and biological pathways can be followed for the production of Hydrogen. Dark fermentation by bacteria becomes an accepted and easier method for the production of hydrogen. The compounds like Hydrogen $\left(\mathrm{H}_{2}\right)$, carbon dioxide $\left(\mathrm{CO}_{2}\right)$, and simple organic compounds like volatile fatty acids (VFAs) and alcohols are formed by the fermentation of carbohydrates by large groups of obligate or facultative anaerobic bacteria. Electrons responsible for the production and generation of 
hydrogen generally come from oxidation of substrate to pyruvate and the second electron comes from the conversion of pyruvate to volatile fatty acids and alcohols [5]. In the first stage, Nicotinamide Adenine Dinucleotide Hydrogen (NADH) is generated by the oxidation of the substrate to pyruvate. Pyruvate is converted to acetyl-CoA in the second stage. Formate is formed by the help of Pyruvate Formate Lyase (PFL) and reduced Ferredoxin is formed from Pyruvate Ferredoxin Oxidoreductase (PFOR). These depend on the organisms which produce Hydrogen $\left(\mathrm{H}_{2}\right)$ where the reaction takes place. In the pathway of PFL, Formate Hydrogen Lyase is used by some organisms which contain hydrogenase, and formate is converted to $\mathrm{H}_{2}$ and $\mathrm{CO}_{2}$. Reduced Ferredoxin is produced in the PFOR pathway [6]. The VFAs are generated when pyruvate enters the acidogenic pathway.

Degradation of Substrates in $A D$ ensures the interconversion of metabolites, as a result, the probability of getting reduced equivalents in the cell is increased. The transfer of electron through various steps to produce hydrogen in the fermentative process is shown in Fig. 1. The $\mathrm{H}^{+}$released from redox mediators like Nicotinamide Adenine Dinucleotide Hydrogen (NADH) and Flavin Adenine Dinucleotide Hydrogen (FADH) is removed due to NADH-dehydrogenase which finally reduces the $\mathrm{H}_{2}$ by the help of the hydrogenase (HydA enzyme) which is produced by the oxidized (Ferredoxin) Fd (co-factor). Electron transport through Q-pool is facilitated by the motile carrier (quinone) proteins and some membranebound complexes of proteins like NADH dehydrogenase and Cytochrome bc-1. The continuous interconversions take place from $\mathrm{Q}$ and $\mathrm{H}^{+}$which is converted to $\mathrm{QH}_{2}$ then $\mathrm{QH}_{2}$ again converted to $\mathrm{Q}$ and $\mathrm{H}^{+}$ which transfers electrons $\mathrm{e}^{-}$to the Cytochrome bc- 1 complex and then Cytochrome aa3. The electron $\left(\mathrm{e}^{-}\right)$ is donated by the reduced Fd to the activated site of the HydA enzyme and this enzyme helps in the reduction of $\mathrm{H}^{+}$with this electron $\left(\mathrm{e}^{-}\right)$to produce molecular hydrogen [7].

Hydrogen produced by dark fermentation is satisfactory but the performance yields can be improved by following various methods. These methods include pre-treatment like heat-shock, acid or alkali treatment, etc. The addition of certain additives such as calcium oxide $(\mathrm{CaO})$ and calcium peroxide $\left(\mathrm{CaO}_{2}\right)$ results in a significant enhancement in hydrogen production during the fermentation of wheat straw [8]. Further, an enhancement in the rate of hydrolysis reaction due to the addition of $\mathrm{CaO}_{2}$ during the anaerobic digestion (AD) of corn straw was identified by Fu et al. [9]. Similarly, Chen et al. [10] investigated the dewatering properties of waste sludge using $\mathrm{CaO}_{2}$ and concluded that the filtration was improved by adding $20 \mathrm{mg}$ $\mathrm{g}^{-1}$ total suspended solid due to the enhanced oxidation which was further deteriorated at a higher dosage due to the extensive release of polymeric substances such as protein. Wang and Li [11] observed substantial enhancement in the degradation efficiency by using the combination of $\mathrm{CaO}_{2}$ and microwave pretreatment resulting in higher methane generation. However, none of the above works have used food waste and cow dung as the feedstock to investigate the effect of $\mathrm{CaO}_{2}$ on hydrogen fermentation. Some efforts have also been given to use calcium carbonate $\left(\mathrm{CaCO}_{3}\right)$ during the anaerobic digestion. Zhang and Wang [12] identified enhanced hydrogen fermentation with reduced lag phase by adding $\mathrm{CaCO}_{3}$ enriched white mud during the fermentation of food waste. It was found that the stability and the alkalinity of the process were enormously optimized resulting in increased hydrogen generation. Liu et al. 
[13] reported significant improvement in hydrogen and total fatty acid production by adding carbonate in the co-digestion of glucose and leachate maintained at alkaline conditions. The addition of carbonate also restrains the inhibitory effect of $\mathrm{Ca}^{2+}$ upon hydrogenase resulting in enhanced hydrogen generation. The accumulation of volatile fatty acid was enhanced during the $A D$ of food waste by adding lime mud (enriched with $\mathrm{CaCO}_{3}$ ) due to the increased alkalinity along with the presence of several other compounds like calcium and magnesium which facilitates the microbial activity during the reaction [14]. The improved process stability and hydrogen generation were further confirmed by the presence of $\mathrm{CaCO}_{3}$ and $\mathrm{NaOH}$ with the addition of $1-4 \mathrm{~g}$ lime mud during the hydrogen fermentation of food waste [15]. Moreover, the addition of $\mathrm{CaCO}_{3}$ showed a promising effect on hydrogen fermentation but its use is limited with other forms such as lime mud rather than a primary additive. The addition of copper oxide (CuO) and zinc oxide ( $\mathrm{ZnO}$ ) also served as interesting additives for the researchers to investigate the hydrogen fermentation. Numerous experiments have been performed in this regard to improve hydrogen production. Chen et al. [16] observed that the performance and the microbial activity were enhanced by the supplementation of nano-carbon powder and nano-aluminium oxide whereas the use of nano-ZnO and nano-CuO appreciably reduce the microbial action in addition to the performance of the anaerobic fermentation process. Zheng et al. [17] observed a reduced performance in the AD process by using the $\mathrm{ZnO}$ nanoparticle but the performance was found identical to the control group when the combination of $\mathrm{ZnO}$ and $\mathrm{TiO}_{2}$ was used as the multi engineered nanoparticle material. Zhang et al. [18] identified a higher accumulation of volatile fatty acid by adding $\mathrm{ZnO}$ nanomaterial compared to the control sample mainly due to the effect of $\mathrm{Zn}^{2+}$ during the $A D$ of waste activated sludge. Mu et al. [19] found that nano-ZnO inhibits the methane generation by suppressing the enzyme activity during sludge hydrolysis acidification and methane generation. Luna-del Risco et al. [20] revealed that the toxicity of the microorganism was regulated by the size of $\mathrm{CuO}$ and $\mathrm{ZnO}$ particles with considerable effect on biogas and methane generation. Most of the research on $\mathrm{CuO}$ and $\mathrm{ZnO}$ addition on anaerobic digestion is based on the nanoparticle rather than the bulk particle of these additives. However, it is suggested from the literature survey that the addition of bulk organic compounds as well as nanomaterials can improve the hydrogen fermentation during the co-digestion process.

It is clear from the literature study that the performance and the microbial activity during the anaerobic co-digestion process could be enhanced by the supplementation of various additives. Though numerous experiments have been conducted by using $\mathrm{CaO}_{2}, \mathrm{ZnO}, \mathrm{CuO}$, and $\mathrm{CaCO}_{3}$, there is a significant research gap to investigate the effect of these additives on the hydrogen fermentation of food waste and cow dung which has never been studied previously. To enhance the hydrogen production from the anaerobic co-digestion, a precise investigation is needed on the use of these additives during the hydrogen fermentation. Therefore in the present work, a novel investigation on the effect of $\mathrm{CaO}_{2}, \mathrm{ZnO}, \mathrm{CuO}$, and $\mathrm{CaCO}_{3}$ addition on the anaerobic fermentation of food waste, cow dung, and sludge solution was carried out and compared with the control sample in which no additives were added. The finding of the work engenders encouraging outcomes towards the enhanced hydrogen fermentation. 


\section{Materials And Methods \\ 2.1. Substrate and inoculum}

The food waste (FW) was accumulated from the university canteen of ITER, Odisha, India. The nonbiodegradable substances such as bones, eggshells, and plastic present inside the FW were removed manually and then the FW was shredded using a home grinder by diluting with tap water to prepare the slurry. The cow dung (CD) was collected from a nearby dairy farm and the slurry was prepared by mixing with tap water. The substrate was a mixture of FW and CD slurries in equal proportion. The sludge solution (SS) was accumulated from the wastewater treatment plant (Bhubaneswar, India) located nearby. It was used as the inoculum during the experiment. The characteristics of food waste, cow dung, and sludge solution were presented in Table 1. The substrate and inoculum were used in the experiment without any pretreatment.

Table 1

Characteristics of Food waste, Cow dung, and Sludge solution used for the experiment.

\begin{tabular}{|llll|}
\hline Parameter & Food waste & Cow dung & Sludge solution \\
\hline Total solid (\%) & $10.3 \pm 0.06$ & $67.37 \pm 0.09$ & $9.6 \pm 0.04$ \\
\hline Volatile solid (\%) & $8.7 \pm 0.15$ & $34.71 \pm 0.34$ & $7.3 \pm 0.07$ \\
\hline $\mathrm{pH}$ & $4.4 \pm 0.1$ & $6.7 \pm 0.3$ & $7.2 \pm 0.1$ \\
\hline Carbon (\%) & $48.6 \pm 0.31$ & $41.54 \pm 0.43$ & $24.58 \pm 0.18$ \\
\hline Hydrogen (\%) & $6.5 \pm 0.14$ & $3.57 \pm 0.36$ & $3.29 \pm 0.21$ \\
\hline Oxygen (\%) & $32.46 \pm 0.26$ & $37.58 \pm 0.41$ & $49.64 \pm 0.34$ \\
\hline Nitrogen (\%) & $3.16 \pm 0.17$ & $2.71 \pm 0.08$ & $1.64 \pm 0.10$ \\
\hline Sulphur (\%) & $0.4 \pm 0.04$ & $0.09 \pm 0.003$ & $0.61 \pm 0.03$ \\
\hline Ash (\%) & $5.29 \pm 0.12$ & $12.78 \pm 0.23$ & $46.4 \pm 0.30$ \\
\hline Moisture content (\%) & $82.6 \pm 0.46$ & $79.65 \pm 0.52$ & $98.5 \pm 0.67$ \\
\hline Fixed carbon (\%) & $12.29 \pm 0.09$ & $10.64 \pm 0.11$ & $8.73 \pm 0.21$ \\
\hline Cellulose (\%) & $0.84 \pm 0.03$ & $2.187 \pm 0.07$ & $\mathrm{ND}$ \\
\hline Hemicellulose (\%) & $0.38 \pm 0.04$ & $2.038 \pm 0.06$ & $\mathrm{ND}$ \\
\hline Lignin (\%) & $0.29 \pm 0.07$ & $3.273 \pm 0.05$ & $\mathrm{ND}$ \\
\hline Note: “ND" signifies the parameter was not determined. \\
\hline
\end{tabular}

\subsection{Experimental methodology}


The experiment was performed in conical glass reactors with a volume of $1 \mathrm{~L}$. The reactors were loaded with the substrate to inoculum ratio of $1: 3$ on a volume basis. Previously experiments were conducted at the various substrate to inoculum ratio from 1:1 to 1:5 to find the optimum ratio for maximum hydrogen generation. The consequence of substrate to inoculum proportion on hydrogen production was explained in our earlier work [21]. One of the reactors (control) did not receive any additive while the other reactors were added with $\mathrm{CaO}_{2}, \mathrm{ZnO}, \mathrm{CuO}$, and $\mathrm{CaCO}_{3}$ at a dosage of $2 \mathrm{mg} \mathrm{L}^{-1}$ according to the earlier studies [22, 23]. After proper mixing, nitrogen gas was used for purging inside the reactors to confirm the anaerobic condition. The reactors were sealed immediately with rubber stoppers and placed on the magnetic stirrer as shown in Fig. 2. The temperature of the water was controlled by PT 100 thermostatic probe to maintain a constant temperature of $37 \pm 1{ }^{\circ} \mathrm{C}$ throughout the experimentation based on the earlier study [21]. Each of the experiments was conducted thrice and the average value obtained was used for better accuracy.

\subsection{Analytical method}

Total solids, volatile solids, $\mathrm{pH}$, ash, moisture, and fixed carbon were measured by following the standard methods [24]. The elemental concentration of carbon, hydrogen, oxygen, nitrogen, and sulfur was measured by CHNS elemental interpreter (Nario EL III). Cellulose, hemicellulose, and lignin concentrations were evaluated followed by the standard methods [25]. Scanning electron microscopy (SEM) was carried out using a JSM-JEOL 6360 scanning electron microscope provided with an auto coater for coating which is automatically adjusted and varied according to the sample. The instrument was operated with an accelerating voltage of $15 \mathrm{kV}$. The gas composition was analyzed in a gas chromatograph (GC-2010, $\mathrm{CIC}$, Baroda) provided with a stainless steel column $(2 \mathrm{~m} \times 3 \mathrm{~mm})$ and a thermal conductivity detector. The gas sample was collected in a pressure lock airtight syringe ( $\mathrm{VICl}$, USA) and inserted into the chromatograph to analyze the composition. The carrier gas (nitrogen) was supplied with a flow rate of $20 \mathrm{~mL} \mathrm{~min}{ }^{-1}$. The composition of the gas was monitored daily throughout the experiment. The water displacement strategy was used for the measurement of gas volume produced during the process.

\section{Results And Discussion}

\subsection{Microstructural characterization of the additives}

The SEM image of $\mathrm{CaO}_{2}$ represents a uniform particle size distribution of as shown in Fig. 3a. The structure and dispersion of particles show higher uniformity compared to the other additives which facilitate the hydrogen fermentation due to increased surface contact of the microorganism with the feedstock. On the other hand, a closely packed microstructure as well as a non-uniform distribution can be observed from the SEM image of CuO (Fig. 3b) due to the lower solubility which results in reduced microbial growth during the reaction. Similarly, the SEM image of ZnO (Fig. 3c) shows an unseparated and closed structure but it is slightly dispersed compared to $\mathrm{CuO}$. The particle size distribution of both $\mathrm{CuO}$ and $\mathrm{ZnO}$ represents that the particles are highly agglomerated and incompletely separated promoting a less encouraging effect on the hydrogenase microbial action with the feedstock during the 
initial stages of the co-digestion. The crystallographic structure of $\mathrm{CaCO}_{3}$ (Fig. 3d) shows rhombohedral crystals with dense and grouped particles. The crystals are also undefined with agglomeration which deteriorates the performance of the system causing a reduced hydrogen fermentation during codigestion. Moreover, the crystallographic characterization signifies that $\mathrm{CaO}_{2}$ leads to the enhanced hydrogen fermentation compared to the other additives. Similar results on the microstructural configuration of the additives have also been reported previously in the literature [26-29].

\subsection{Effect of the additives on hydrogen concentration}

The hydrogen concentration of the five reactors is shown in Fig. 4. It was observed that the hydrogen concentration in the control sample remains within the range of $17 \%$ whereas a higher concentration of hydrogen was found by supplementing the additives inside the reactors. The maximum hydrogen concentration after the addition of $\mathrm{CaO}_{2}, \mathrm{ZnO}, \mathrm{CuO}$, and $\mathrm{CaCO}_{3}$ was found to be $26.43 \%, 21.67 \%, 17.64 \%$, and $20.84 \%$ respectively. The highest concentration of hydrogen was observed by adding $\mathrm{CaO}_{2}$ while the lowest concentration was observed by adding $\mathrm{CuO}$ as an additive with the feedstock. The hydrogen concentration gradually increases in all the reactors up to the fourth or fifth day when it reached the peak after that the concentration decreases significantly throughout the anaerobic fermentation. It was identified from the above results that additives could enhance the hydrogen concentration during the fermentation especially when the feedstock was supplied with $\mathrm{CaO}_{2}$. The addition of $\mathrm{ZnO}$ and $\mathrm{CaCO}_{3}$ has a moderate effect whereas $\mathrm{CuO}$ did not show any significant impact on the hydrogen concentration throughout the anaerobic fermentation process.

The fermentation process of hydrogen was significantly enhanced by adding $\mathrm{CaO}_{2}$ compared to the other additives. There are two main reasons involved in this observation. Firstly the dissociation of $\mathrm{CaO}_{2}$ results in the generation of $\mathrm{OH} \otimes$ and $\cdot \mathrm{O}_{2} \rrbracket$ that facilitate the hydrolysis of protein along with carbohydrate due to the increased breakdown of the microorganisms and the release of the amino acids [30]. Secondly, the release of $\mathrm{OH} \otimes$ and $\mathrm{H}_{2} \mathrm{O}_{2}$ as the intermediate products due to the reaction between $\mathrm{CaO}_{2}$ and water leads to an increased reaction rate during the initial stages of $A D$ [31]. These two factors are primarily responsible for the enhanced hydrogen generation during the fermentation process. The dissociation of $\mathrm{ZnO}$ and $\mathrm{CuO}$ results in the formation of $\mathrm{Zn}^{2+}$ and $\mathrm{Cu}^{2+}$ ions that lead to an increase in the toxicity of the medium and inhibit the microbial growth during the $A D$ [32]. Also, the toxic nature of the ions was responsible for the lower volatile fatty acid generation caused by the decreased hydrolysis of protein [18]. The addition of $\mathrm{CaCO}_{3}$ causes less ion conductivity and lower $\mathrm{pH}$ which results in a lower concentration of hydrogen during the acidification [33]. Also the reduced ion activity of $\mathrm{Ca}^{2+}$ and $\mathrm{CO}_{3}{ }^{2-}$ leads to the lower rate of reaction during the hydrolysis. Moreover, the combined effect of lower $\mathrm{pH}$ and higher toxicity results in lower hydrogen formation during the reaction. Baldi et al. [34] observed a maximum hydrogen percentage of $22.9 \%$ during the $A D$ of activated sludge with food waste. A similar result was also reported by Yeshanew et al. [35] through the anaerobic fermentation of food dissipate.

\subsection{Effect of the additives on cumulative hydrogen yield}


Figure 5 shows the cumulative hydrogen yield of all the reactors. It was observed to be lowest in the control sample while the highest cumulative hydrogen yield was obtained by adding $\mathrm{CaO}_{2}$ with the feedstock. The cumulative hydrogen yield of all the reactors after $15 \mathrm{~d}$ of fermentation was found to be $101.57 \mathrm{~mL} \mathrm{~g}^{-1} \mathrm{TS}$ (control), $114.1 \mathrm{~mL} \mathrm{~g}^{-1} \mathrm{TS}\left(\mathrm{CaO}_{2}\right), 109.27 \mathrm{~mL} \mathrm{~g}^{-1} \mathrm{TS}(\mathrm{ZnO}), 104.87 \mathrm{~mL} \mathrm{~g}^{-1} \mathrm{TS}$ (CuO), and $107.38 \mathrm{~mL} \mathrm{~g}^{-1} \mathrm{TS}\left(\mathrm{CaCO}_{3}\right)$ respectively. It was found to follow the order $\mathrm{CaO}_{2}>\mathrm{ZnO}>\mathrm{CaCO}_{3}>\mathrm{CuO}>$ control. The hydrogen production was accelerated by the additives compared to the control samples during the reaction. Hydrogen generation was enhanced up to $11 \%$ by adding $\mathrm{CaO}_{2}$ with the feedstock compared to the control sample in which no additives were added during the fermentation process. The increase in hydrogen generation by adding $\mathrm{ZnO}, \mathrm{CuO}$, and $\mathrm{CaCO}_{3}$ was found to be $7 \%, 3 \%$, and $5.4 \%$ respectively compared to the control one. It was clear from the observation that additives could increase hydrogen production significantly during the anaerobic fermentation of food waste.

The cumulative hydrogen yield was significantly enhanced by adding $\mathrm{CaO}_{2}$ due to the release of alkali, $\cdot \mathrm{OH}$, and $\mathrm{O}_{2} \rrbracket$ from the decomposition of $\mathrm{CaO}_{2}$ which facilitate the hydrolysis of the feedstock producing more amount of hydrogen during the early stages of $A D$ [31]. Also, $\mathrm{CaO}_{2}$ was more prone towards the inhibition of hydrogen consuming bacteria rather than the hydrogenase which is also responsible for the higher hydrogen generation during the reaction [36]. The higher toxicity of $\mathrm{ZnO}$ and $\mathrm{CuO}$ restrict the growth of hydrogen fermentative bacteria during the earlier stages of $A D$ which is the main reason for lower hydrogen generation when compared to $\mathrm{CaO}_{2}$ [20]. However, the cumulative hydrogen yield by adding $\mathrm{ZnO}$ and $\mathrm{CuO}$ was found to be higher compared to the control sample due to the enhanced hydrolysis of the feedstock during the initial period of digestion. The lower $\mathrm{pH}$ of the feedstock along with the lower ion activity of $\mathrm{Ca}^{2+}$ and $\mathrm{CO}_{3}{ }^{2-}$ results in lower hydrogen generation by adding $\mathrm{CaCO}_{3}$ as an additive during the hydrogen fermentation [33]. Nevertheless, an increase in hydrogen generation compared to the control sample was observed by adding $\mathrm{CaCO}_{3}$ due to the stimulated growth of hydrogenase caused by the release of ion during the acidification of the feedstock. The cumulative hydrogen production of $60.23 \mathrm{~mL} \mathrm{~g}^{-1} \mathrm{VS}$ was detected during the anaerobic fermentation of food waste by Li et al. [37]. A comparable outcome was also reported by other authors during the AD of peanut shells [38].

\subsection{Effect of the additives on carbon dioxide concentration}

The effect of different additives on carbon dioxide concentration compared to the control sample is presented in Fig. 6. A significant increase in carbon dioxide proportion was observed through the initial period ( 7 to $8 \mathrm{~d}$ ) of $A D$ in all the cases. After the attainment of the peak hydrogen concentration it gradually decreases during the remaining days of digestion. The maximum carbon dioxide concentration in the control, $\mathrm{CaO}_{2}, \mathrm{ZnO}, \mathrm{CuO}$, and $\mathrm{CaCO}_{3}$ reactors was found to be $57.63 \%, 54.62 \%, 58.37 \%, 59.2 \%$, and $58.4 \%$ respectively. The carbon dioxide concentration of $\mathrm{CaO}_{2}$ was lower than the control sample but $\mathrm{ZnO}$, $\mathrm{CuO}$, and $\mathrm{CaCO}_{3}$ result in higher carbon dioxide concentration compared to the control sample. The addition of $\mathrm{CaO}_{2}$ compared to the other additives significantly reduces the carbon dioxide formation which leads to improved hydrogen formation during the acidogenic stages of the reaction. However, the 
addition of $\mathrm{ZnO}, \mathrm{CuO}$, and $\mathrm{CaCO}_{3}$ reduced the hydrogen generation compared to $\mathrm{CaO}_{2}$ which was the consequence of higher carbon dioxide concentration during the $A D$.

Lower carbon dioxide concentration in the $\mathrm{CaO}_{2}$ reactor results in the higher hydrogen concentration compared to the other reactors. This may be due to the formation of alkali, $\mathrm{OH}$, and $\cdot \mathrm{O}_{2} \rrbracket$ which accelerate the hydrogen fermentation and suppress the generation of carbon dioxide during the reaction [31]. The higher carbon dioxide concentration by adding $\mathrm{ZnO}, \mathrm{CuO}$, and $\mathrm{CaCO}_{3}$ was due to the increased toxicity of the medium caused by the ionic activity of $\mathrm{Zn}^{2+}, \mathrm{Cu}^{2+}$, and $\mathrm{Ca}^{2+}$ respectively [39]. The acidification of the feedstock during the initial period of digestion was enhanced by the ions while the hydrogenase microbial growth was restricted due to the toxicity inside the reactor. A similar observation on carbon dioxide concentration was reported by the other researchers through the anaerobic fermentation of food residue $[40,41]$. The results showed a significant variation in the carbon dioxide concentration by using the additives compared to the control sample. The addition of $\mathrm{CaO}_{2}$ exhibited a positive effect by reducing the carbon dioxide concentration whereas $\mathrm{ZnO}, \mathrm{CuO}$, and $\mathrm{CaCO}_{3}$ addition increase the concentration of carbon dioxide which is undesirable during the hydrogen fermentation.

\subsection{Effect of the additives on maximum hydrogen and carbon dioxide concentration}

The maximum hydrogen concentration was inversely proportional to the carbon dioxide concentration as shown in Fig. 7. The highest hydrogen concentration was detected in the $\mathrm{CaO}_{2}$ sample with the lowest carbon dioxide concentration in comparison with other reactors. As the hydrogen concentration increases with $\mathrm{CaO}_{2}$ compared to the control the carbon dioxide concentration was reduced simultaneously. Further decrease in the hydrogen concentration increases carbon dioxide concentration. Among the additives, the lowest hydrogen concentration was observed to be $17.64 \%$ in the $\mathrm{CuO}$ reactor that leads to the highest carbon dioxide concentration of $59.2 \%$. The maximum hydrogen concentration of $26.34 \%$ was observed in the $\mathrm{CaO}_{2}$ reactor with the lowest carbon dioxide concentration of $54.62 \%$ among all the reactors. It was noted that the addition of $\mathrm{CaO}_{2}$ significantly promote the hydrogen generation by reducing the carbon dioxide concentration while the addition of $\mathrm{ZnO}, \mathrm{CuO}$, and $\mathrm{CaCO}_{3}$ has a less significant effect on hydrogen generation but still the additives have a positive effect on hydrogen and carbon dioxide concentration compared to the control reactor.

The disintegration of $\mathrm{CaO}_{2}$ leads to the generation of alkali, $\cdot \mathrm{OH}$, and $\cdot \mathrm{O}_{2} \mathrm{Q}$ those are primarily responsible for the increased hydrogen production by increasing the microbial disintegration during the reaction [42]. The enhancement of hydrogen generation simultaneously results in the reduction of carbon dioxide formed during the acidification. Also, the decomposition of $\mathrm{CaO}_{2}$ increased the alkali generation during hydrolysis that facilitates the higher bacterial activity inside the feedstock [43]. As the hydrogen fermentation increases by adding $\mathrm{CaO}_{2}$ the microbial activity could not shift towards the carbon dioxide fermentation which results in the lower carbon dioxide concentration compared to the other reactors. Moreover, the formation of $\mathrm{Ca}^{2+}$ due to the decomposition of $\mathrm{CaO}_{2}$ did not show a significant effect on 
the reduced growth of hydrogenase compared to the combined effect of alkali, $\cdot \mathrm{OH}$, and $\cdot \mathrm{O}_{2} \rrbracket$ during the reaction [44]. Lower alkali generation in $\mathrm{ZnO}, \mathrm{CuO}$, and $\mathrm{CaCO}_{3}$ reactors inhibited the hydrogenase bacterial growth during the acidification resulting in the lower hydrogen generation compared to the $\mathrm{CaO}_{2}$ reactor. The carbon dioxide fermentation was enhanced due to the inhibition of hydrogenase bacterial growth during the initial period of digestion. Also, the lower hydrogen concentration was the upshot of higher toxicity inside the reactors due to the formation of $\mathrm{Zn}^{2+}, \mathrm{Cu}^{2+}$, and $\mathrm{Ca}^{2+}$ during the decomposition of $\mathrm{ZnO}$, $\mathrm{CuO}$, and $\mathrm{CaCO}_{3}$ respectively [45]. The increase in hydrogen generation with a simultaneous decrease in carbon dioxide concentration was reported by Algapani et al. [46] in which a maximum hydrogen concentration of $64 \%$ was observed with a reduced carbon dioxide concentration of $32 \%$ through the multi-stage digestate recirculated anaerobic fermentation of food residue.

\subsection{Effect of the additives on hydrogen production}

The cumulative hydrogen yield and the hydrogen concentration of all the reactors are presented in Fig. 8. The cumulative hydrogen yield was observed to be directly proportional to the corresponding hydrogen concentration of the reactor where the maximum hydrogen concentration and the cumulative hydrogen yield were observed to be $26.34 \%$ and $114.1 \mathrm{~mL} \mathrm{~g}^{-1} \mathrm{TS}$ respectively in the $\mathrm{CaO}_{2}$ reactor. The lowest value of the hydrogen concentration and the cumulative hydrogen yield among all the reactors were observed to be $17 \%$ and $101.57 \mathrm{~mL} \mathrm{~g}^{-1}$ TS respectively in the control reactor. It is worth noting that the additives have more or less increased hydrogen generation in comparison with the control sample during the anaerobic fermentation. The lowest hydrogen production among the additives was observed with $\mathrm{CuO}$ while the highest production was found with the $\mathrm{CaO}_{2}$ sample. The maximum hydrogen concentration in the $\mathrm{ZnO}, \mathrm{CuO}$, and $\mathrm{CaCO}_{3}$ reactors was found to be $21.67 \%, 17.64 \%$, and $20.84 \%$ respectively while the cumulative hydrogen yield was identified to be $109.27 \mathrm{~mL} \mathrm{~g}^{-1} \mathrm{TS}, 104.87 \mathrm{~mL} \mathrm{~g}^{-1} \mathrm{TS}$, and $107.38 \mathrm{~mL} \mathrm{~g}^{-1}$ TS respectively from the same reactors. The cumulative hydrogen production demonstrated a direct link among the hydrogen concentration when the additives are used with the feedstock through the anaerobic co-fermentation.

The increased hydrogen generation in the $\mathrm{CaO}_{2}$ reactor corresponds to the increased hydrogenase growth during the acidogenesis in comparison with the other samples. The higher $\mathrm{pH}$ in the control sample results in lower volatile fatty acid accumulation during the acidogenic stage of $A D$ which was the main reason for lower hydrogen generation [47]. Also, the microbial degradation of the feedstock was not significantly enhanced as the control reactor did not receive any additive that also results in lower hydrogen production. The lower hydrogen production in the $\mathrm{ZnO}, \mathrm{CuO}$, and $\mathrm{CaCO}_{3}$ reactors mainly resulted due to the increased toxicity of the medium as well as the lower alkali formation which restricts the hydrogenase microbial growth and volatile fatty acid consumption during the initial stages of $A D[45$, 48]. A similar trend of hydrogen generation was identified by Wainaina et al. [49] during the AD of food waste where the organic loading rate serves as the base for the comparison of hydrogen generation.

\section{Conclusion}


The effect of $\mathrm{CaO}_{2}, \mathrm{ZnO}, \mathrm{CuO}$, and $\mathrm{CaCO}_{3}$ as additives during the hydrogen fermentation of food waste and cow dung was experimentally investigated. The additives showed encouraging outcomes on the enhancement of hydrogen generated during the process. The hydrogenase microbial growth was accelerated by using the additives resulting in an enhanced hydrogen concentration up to $9.43 \%$ whereas the cumulative hydrogen yield was increased up to $11 \%$ compared to the control sample which did not receive any additive. The transfer of electron by the reduced ferredoxin co-factor was significantly promoted by the additives towards the activated site of the HydA enzyme that helps in the reduction of $\mathrm{H}^{+}$ with this electron to produce hydrogen during the reaction. Among the additives, $\mathrm{CaO}_{2}$ represented

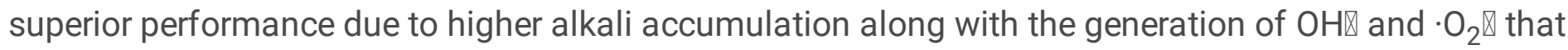
facilitate the enhanced growth of the HydA enzyme to decompose the protein and carbohydrate present inside the feedstock. The release of $\mathrm{Zn}^{2+}$ and $\mathrm{Cu}^{2+}$ ions from $\mathrm{ZnO}$ and $\mathrm{CuO}$ respectively increase the toxicity within the feedstock that leads to the inhibition of the microbial growth resulting in lower hydrogen formation. The reduced ion activity of $\mathrm{Ca}^{2+}$ and $\mathrm{CO}_{3}{ }^{2-}$ liberated from $\mathrm{CaCO}_{3}$ during the reaction resulted in similar observations based on the hydrogen fermentation. Moreover, the additives showed a significant improvement in the hydrogen fermentation process compared to the control sample during the $A D$ of food waste. However, more research is required to reduce the carbon dioxide concentration during the $A D$ process along with the morphological changes in the structure of the additives after long term use. The present work serves as a future scope for the large scale hydrogen production that can be used in the practical field as a renewable source of energy.

\section{Declarations}

\section{Availability of data and materials}

All experimental data generated and used in the manuscript are with authors and will be provided on request to authors.

\section{Competing interests}

The authors declare they have no competing interests.

\section{Funding}

This research did not receive any specific grant from funding agencies in the public, commercial, or notfor-profit sectors.

\section{Authors' contributions}

Chinmay Deheri done the formal analysis, data curation, investigation, methodology, and writing- original draft preparation. Saroj Kumar Acharya done the conceptualization, supervision, visualization, and validation. All authors read and approved the final manuscript. 
Acknowledgements

Not applicable.

\section{References}

1. Gustavson J, Cederberg C, Sonesson U, Van otterdijk R, Meybeck A. Global food losses and food waste - Extent, causes and prevention. FAO. Rome. 2011.

2. Zhang C, Su H, Baeyens J, Tan T. Reviewing the anaerobic digestion of food waste for biogas production. Renewable and Sustainable Energy Reviews. 2014;38:383-392.

3. Deheri C, Acharya SK, Thatoi DN, Mohanty AP. A review on performance of biogas and hydrogen on diesel engine in dual fuel mode. Fuel. 2020;260:116337.

4. Christopher K, Dimitrios R. A review on exergy comparison of hydrogen production methods from renewable energy sources. Energy Environ. Sci. 2012;5:6640-6651.

5. Kraemer JT, Bagley D. Improving the yield from fermentative hydrogen production. Biotechnology Letters. 2007;29:685-695.

6. Ding C, Yang KL, He J. Biological and Fermentative production of hydrogen. Handbook of Biofuels Production. 2016;2e(Ch-11):303-333.

7. Mohan SV. Harnessing of biohydrogen from wastewater treatment using mixed fermentative consortia: process evaluation towards optimization. International Journal of Hydrogen Energy. 2009;34:7460-7474.

8. Zhang J, Kong C, Yang M, Zang L. Comparison of Calcium Oxide and Calcium Peroxide Pretreatments of Wheat Straw for Improving Biohydrogen Production. ACS Omega. 2020;5:9151-9161.

9. Fu SF, Chen KQ, Sun WX, Zhu R, Zheng Y, Zoua H. Improved methane production of corn straw by the stimulation of calcium peroxide. Energy Conversion and Management. 2018;164:36-41.

10. Chen Z, Zhang W, Wang D, Ma T, Bai R, Yu D. Enhancement of waste activated sludge dewaterability using calcium peroxide peroxidation and chemical re-flocculation. Water Research. 2016;103:170181.

11. Wang J, Li Y. Synergistic pretreatment of waste activated sludge using $\mathrm{CaO}_{2}$ in combination with microwave irradiation to enhance methane production during anaerobic digestion. Applied Energy. 2016;183:1123-1132.

12. Zhang J, Wang Q. Buffering and nutrient effects of white mud from ammonia-soda process on thermophilic hydrogen fermentation from food waste. International journal of hydrogen energy. 2013;38:13564-13571.

13. Liu Q, Zhang XL, Jun Z, Zhao AH, Chen SP, Liu F, Tai J, Liu JY, Qian GR. Effect of carbonate on anaerobic acidogenesis and fermentative hydrogen production from glucose using leachate as supplementary culture under alkaline conditions. Bioresource Technology. 2012;113:37-43. 
14. Zhang J, Wang Q, Zheng P, Wang Y. Anaerobic digestion of food waste stabilized by lime mud from papermaking process. Bioresource Technology. 2014;170:270-277.

15. Zhang J, Wang Q, Jiang J. Lime mud from paper-making process addition to food waste synergistically enhances hydrogen fermentation performance. International journal of hydrogen energy. 2013;38:2738-2745.

16. Chen Y, Yang Z, Zhang Y, Xiang Y, Xu R, Jia M, Cao J, Xiong W. Effects of different conductive nanomaterials on anaerobic digestion process and microbial community of sludge. Bioresource Technology. 2020;304:123016.

17. Zheng L, Zhang Z, Tian L, Zhang L, Cheng S, Li Z, Cang D. Mechanistic investigation of toxicological change in $\mathrm{ZnO}$ and $\mathrm{TiO}_{2}$ multi-nanomaterial systems during anaerobic digestion and the microorganism response. Biochemical Engineering Journal. 2019;147:62-71.

18. Zhang L, He X, Zhang Z, Cang D, Nwe KA, Zheng L, Li Z, Cheng S. Evaluating the influences of ZnO engineering nanomaterials on VFA accumulation in sludge anaerobic digestion. Biochem. Eng. J. 2017;125:206-211.

19. $\mathrm{Mu} \mathrm{H}$, Chen $\mathrm{Y}$, Xiao N. Effects of metal oxide nano particles $\left(\mathrm{TiO}_{2}, \mathrm{Al}_{2} \mathrm{O}_{3}, \mathrm{SiO}_{2}, \mathrm{ZnO}\right)$ on waste activated sludge anaerobic digestion. Bioresource Technology. 2011;102:10305-10311.

20. Luna-delRisco M, OrupÕId K, Dubourguier HC. Particle Size effect of $\mathrm{CuO}$ and $\mathrm{ZnO}$ on biogas and methane production during anaerobic digestion. Journal of Hazardous materials. 2011;189:603-608.

21. Deheri C, Acharya SK. An experimental approach to produce hydrogen and methane from food waste using catalyst. International Journal of Hydrogen Energy. 2020;45:17250-17259.

22. Ünsar EK, Çıggın AS, Erdem A, Perendeci NA. Long and short term impacts of $\mathrm{CuO}, \mathrm{Ag}$ and $\mathrm{CeO}_{2}$ nanoparticles on anaerobic digestion of municipal waste activated sludge. Environ. Sci. Process and Impacts. 2016;18:277-288.

23. $\mathrm{Mu} \mathrm{H}$, Chen $\mathrm{Y}$. Long-term effect of $\mathrm{ZnO}$ nanoparticles on waste activated sludge anaerobic digestion. Water Res. 2011;45:5612-5620.

24. APHA. Standard Methods for the Examination of Water and Wastewater. Washington, DC: 21sted. American Public Health Association (APHA); 2005.

25. Sluiter A, Hames B, Ruiz R, Scarlata C, Sluiter J, Templeton D, Crocker D. Determination of Structural Carbohydrates and Lignin in Biomass. National Renewable Energy Laboratory. 2008:1-15.

26. Sun Y, Lyu S, Brusseau ML, Tang P, Jiang W, Gu M, Li M, Lyu Y, Qiu Z, Sui Q. Degradation of trichloroethylene in aqueous solution by nanoscale calcium peroxide in the $\mathrm{Fe}(\mathrm{II})$-based catalytic environments. Separation and Purification Technology. 2019;226:13-21.

27. Jadhav S, Gaikwad S, Nimse M, Rajbhoj A. Copper Oxide Nanoparticles: Synthesis, Characterization and Their Antibacterial Activity. J Clust Sci. 2011;22:121-129.

28. Mohan AC, Renjanadevi B. Preparation of Zinc Oxide Nanoparticles and its Characterization Using Scanning Electron Microscopy (SEM) and X-Ray Diffraction(XRD). Procedia Technology. 2016;24:761 - 766 . 
29. Polowczyk I, Bastrzyk A, Fiedot M. Protein-Mediated Precipitation of Calcium Carbonate. Materials. 2016;9:944.

30. Dahiya S, Sarkar O, Swamy YV, Mohan SV. Acidogenic fermentation of food waste for volatile fatty acid production with co-generation of biohydrogen. Bioresour. Technol. 2015;182:103-113.

31. Li Y, Wang J, Zhang A, Wang L. Enhancing the quantity and quality of short-chain fatty acids production from waste activated sludge using $\mathrm{CaO}_{2}$ as an additive. Water Res. 2015;83:84-93.

32. Gonzalez-Estrella J, Sierra-Alvarez R, Field JA. Toxicity assessment of inorganic nanoparticles to acetoclastic and hydrogenotrophic methanogenic activity in anaerobic granular sludge. J. Hazard Mater. 2013;260:278-285.

33. Salek SS, Bozkurt OD, van Turnhout AG, Kleerebezem R, van Loosdrecht MCM. Kinetics of $\mathrm{CaCO}_{3}$ precipitation in an anaerobic digestion process integrated with silicate minerals. Ecological Engineering. 2016;86:105-112.

34. Baldi F, Pecorini I, lannelli R. Comparison of single-stage and two-stage anaerobic co-digestion of food waste and activated sludge for hydrogen and methane production. Renewable Energy. 2019;143:1755-1765.

35. Yeshanew MM, Frunzo L, Pirozzi F, Lens PNL, Esposito G. Production of biohythane from food waste via an integrated system of continuously stirred tank and anaerobic fixed bed reactors. Bioresource Technology. 2016;220:312-322.

36. Wang D, Zhang D, Xu Q, Liu Y, Wang Q, Ni BJ, Yang Q, Li X, Yang F. Calcium peroxide promotes hydrogen production from dark fermentation of waste activated sludge. Chemical Engineering Journal. 2019;355:22-32.

37. Li Z, Chen Z, Ye H, Wang Y, Luo W, Chang JS, Li Q, He N. Anaerobic co-digestion of sewage sludge and food waste for hydrogen and VFA production with microbial community analysis. Waste Management. 2018;78:789-799.

38. Qi N, Hu X, Zhao X, Li L, Yang J, Zhao Y, Li X. Fermentative hydrogen production with peanut shell as supplementary substrate: Effects of initial substrate, $\mathrm{pH}$ and inoculation proportion. Renewable Energy. 2018;127:559-564.

39. Tong T, Wilke CM, Wu J, Binh CT, Kelly JJ, Gaillard JF, Gray KA. Combined Toxicity of Nano-ZnO and $\mathrm{Nano}_{-\mathrm{TiO}_{2}}$ : From Single- to Multinanomaterial Systems, Environ. Sci. Technol. 2015;49:8113-8123.

40. Ko JH, Wang N, Yuan T, Lü F, He P, Xu Q. Effect of nickel-containing activated carbon on food waste anaerobic digestion. Bioresource Technology. 2018;266:516-523.

41. Janke L, Weinrich S, Leite AF, Sträuber H, Radetski CM, Nikolausz M, Nelles M, Stinner W. Year-round biogas production in sugarcane biorefineries: Process stability, optimization and performance of a two-stage reactor system. Energy Conversion and Management. 2018;168:188-199.

42. Deheri C, Acharya SK. Effect of calcium peroxide and sodium hydroxide on hydrogen and methane generation during the co-digestion of food waste and cow dung. Journal of Cleaner Production. 2021;279:123901. 
43. Wang Y, Wang D, Chen F, Yang Q, Ni BJ, Wang Q, Liu Y. Nitrate addition improves hydrogen production from acidic fermentation of waste activated sludge. Chemosphere. 2019;235:814-824.

44. Li Y, Wang D, Yang G, Yuan X, Xu Q, Liu X, Chen F. The novel pretreatment of $\mathrm{Co}^{2+}$ activating peroxymonosulfate under acidic condition for dewatering waste activated sludge. J. Taiwan Inst. Chem. Eng. 2019;102:259-267.

45. Kasemets K, Ivask A, Dubourguier $\mathrm{HC}$, Kahru A. Toxicity of nanoparticles of $\mathrm{ZnO}, \mathrm{CuO}$ and $\mathrm{TiO}_{2}$ to yeast Saccharomyces cerevisiae, Toxicol. In Vitro. 2009;23:1116-1122.

46. Algapani DE, Qiao W, Ricci M, Bianchi D, Wandera SM, Adani F, Dong R. Bio-hydrogen and biomethane production from food waste in a twostage anaerobic digestion process with digestate recirculation. Renewable Energy. 2019;130:1108-1115.

47. Zhai N, Zhang T, Yin D, Yang G, Wang X, Ren G, Feng Y. Effect of initial pH on anaerobic co-digestion of kitchen waste and cow manure. Waste Manage. 2015;38:126-131.

48. Zayed G, Winter J. Inhibition of methane production from whey by heavy metals-protective effect of sulfide, Appl. Microbiol. Biot. 2000;53:726-731.

49. Wainaina S, Awasthi MK, Horvath IS, Taherzadeh MJ. Anaerobic digestion of food waste to volatile fatty acids and hydrogen at high organic loading rates in immersed membrane bioreactors. Renewable Energy. 2020;152:1140-1148.

\section{Figures}




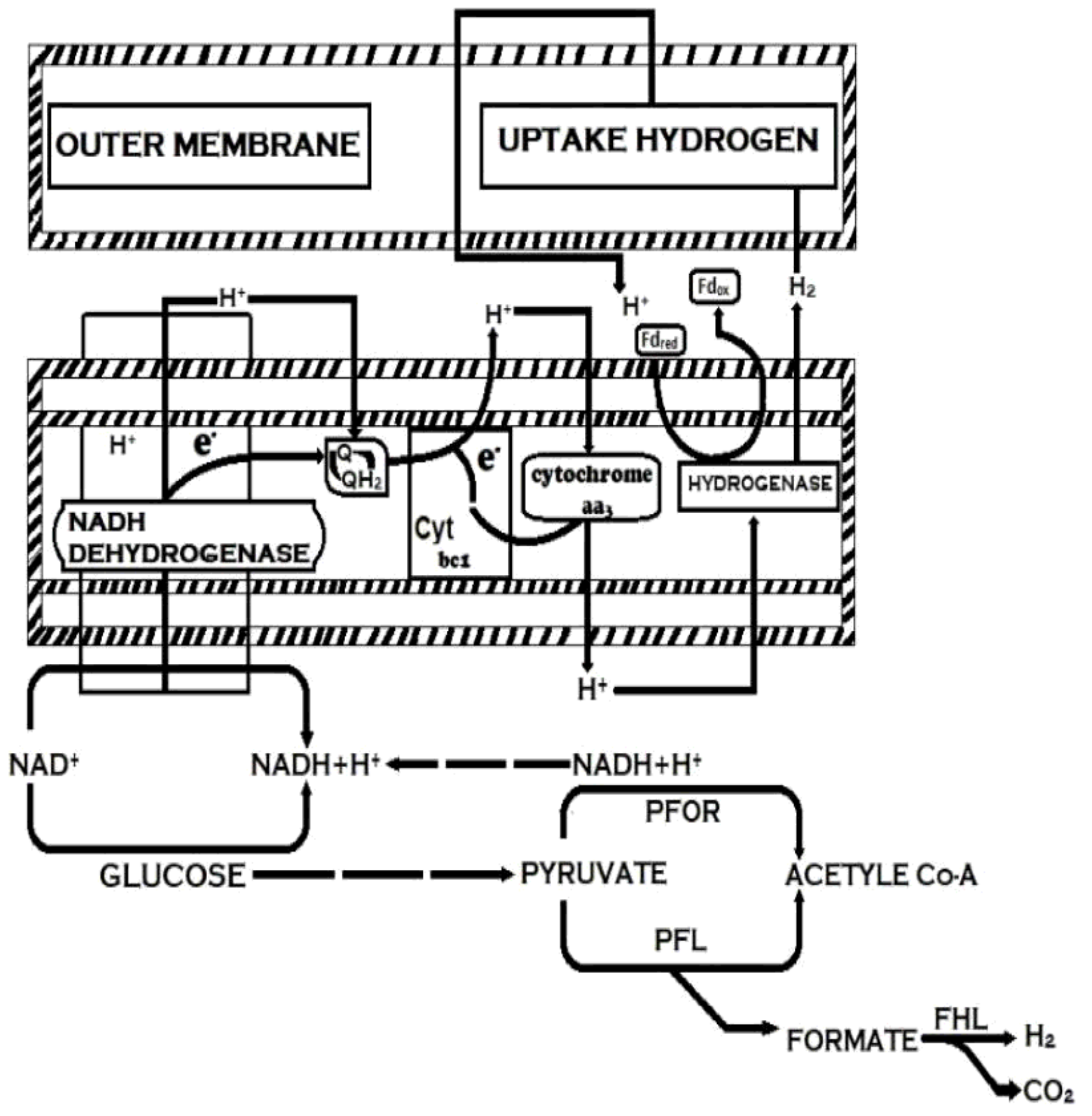

Figure 1

Electron transfer mechanism during the hydrogen fermentation. 


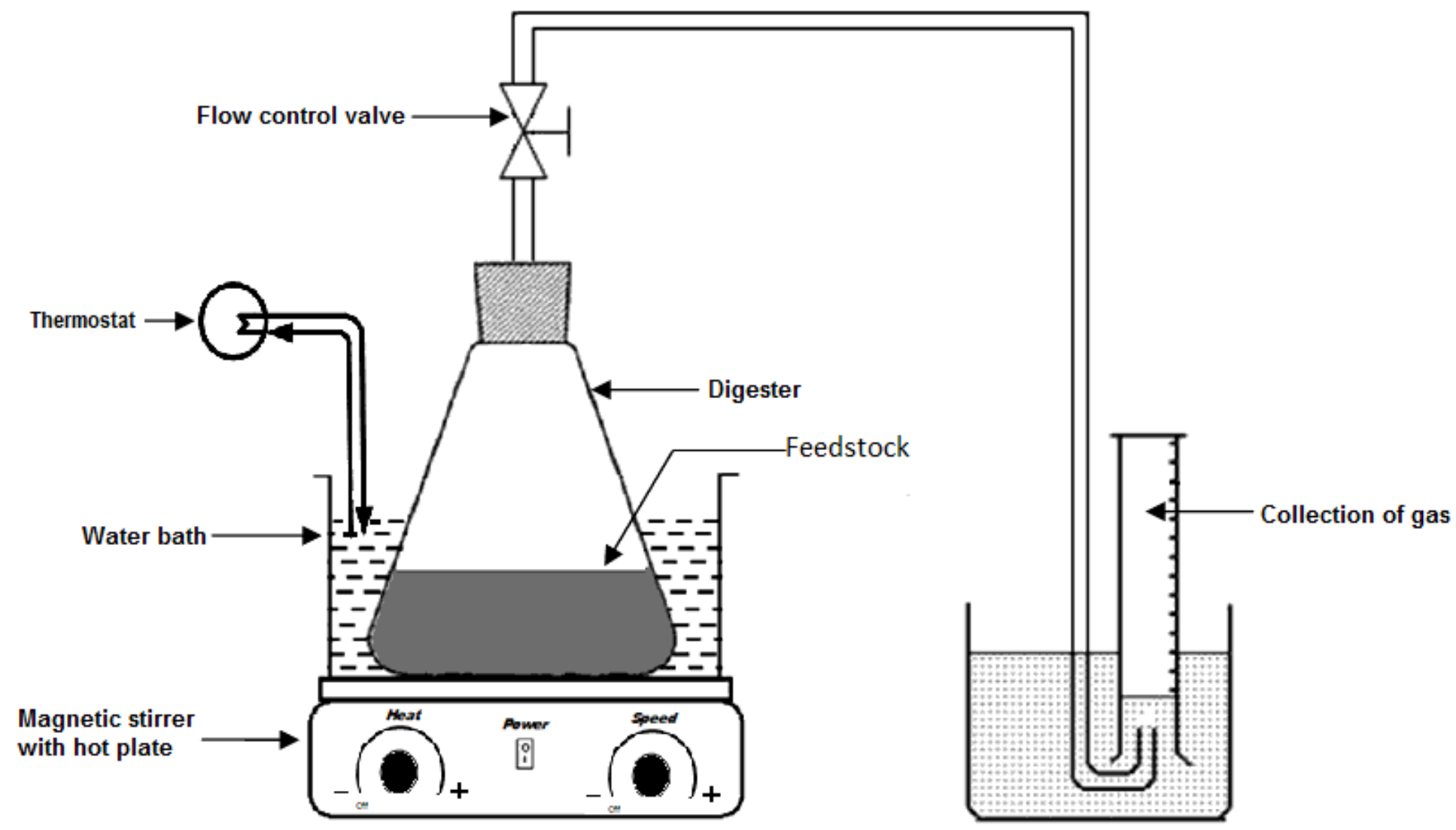

Figure 2

Schematic representation of the experimental arrangement. 

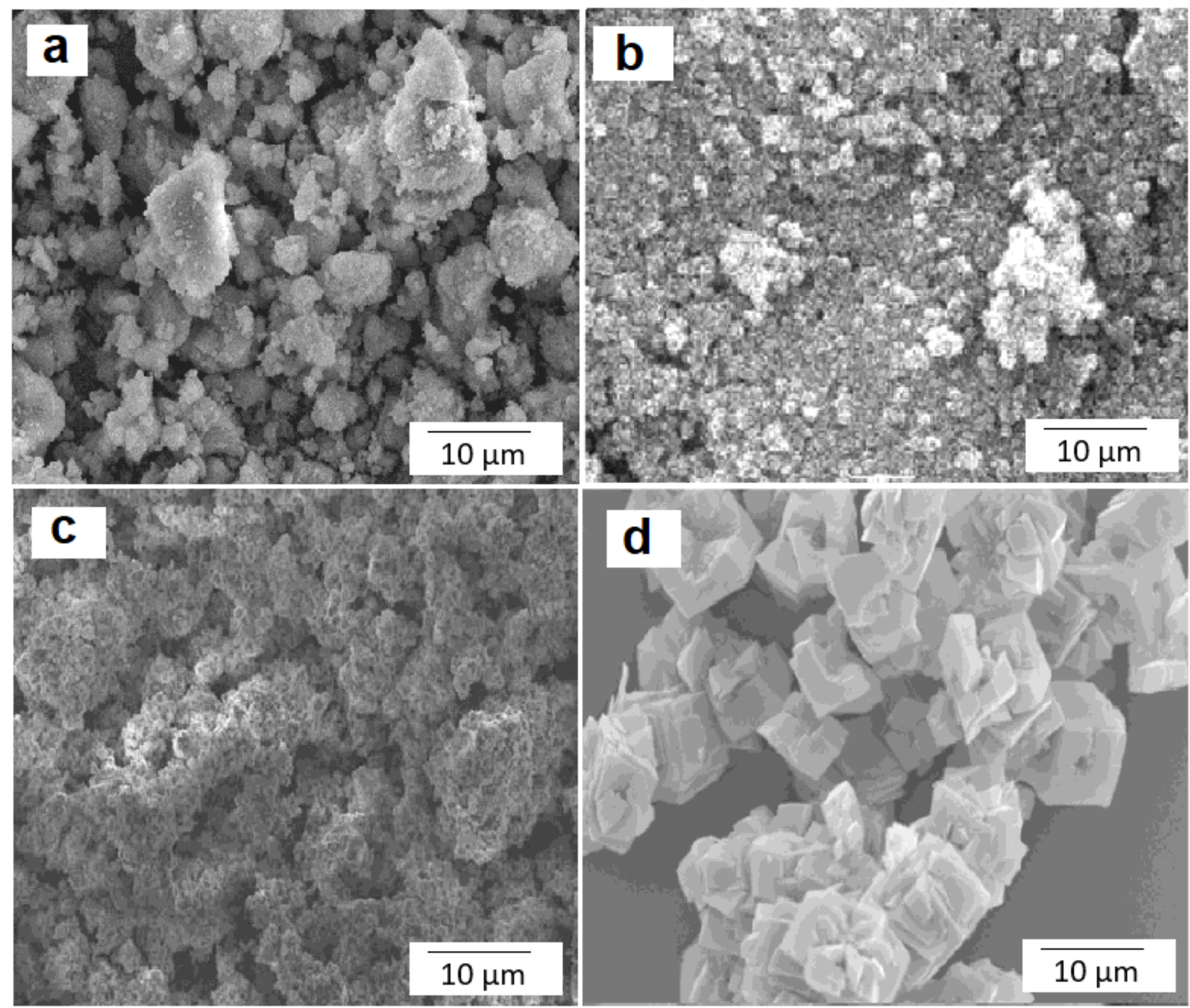

Figure 3

SEM images of (a) $\mathrm{CaO} 2$, (b) $\mathrm{CuO}$, (c) ZnO, and (d) $\mathrm{CaCO} 3$. 


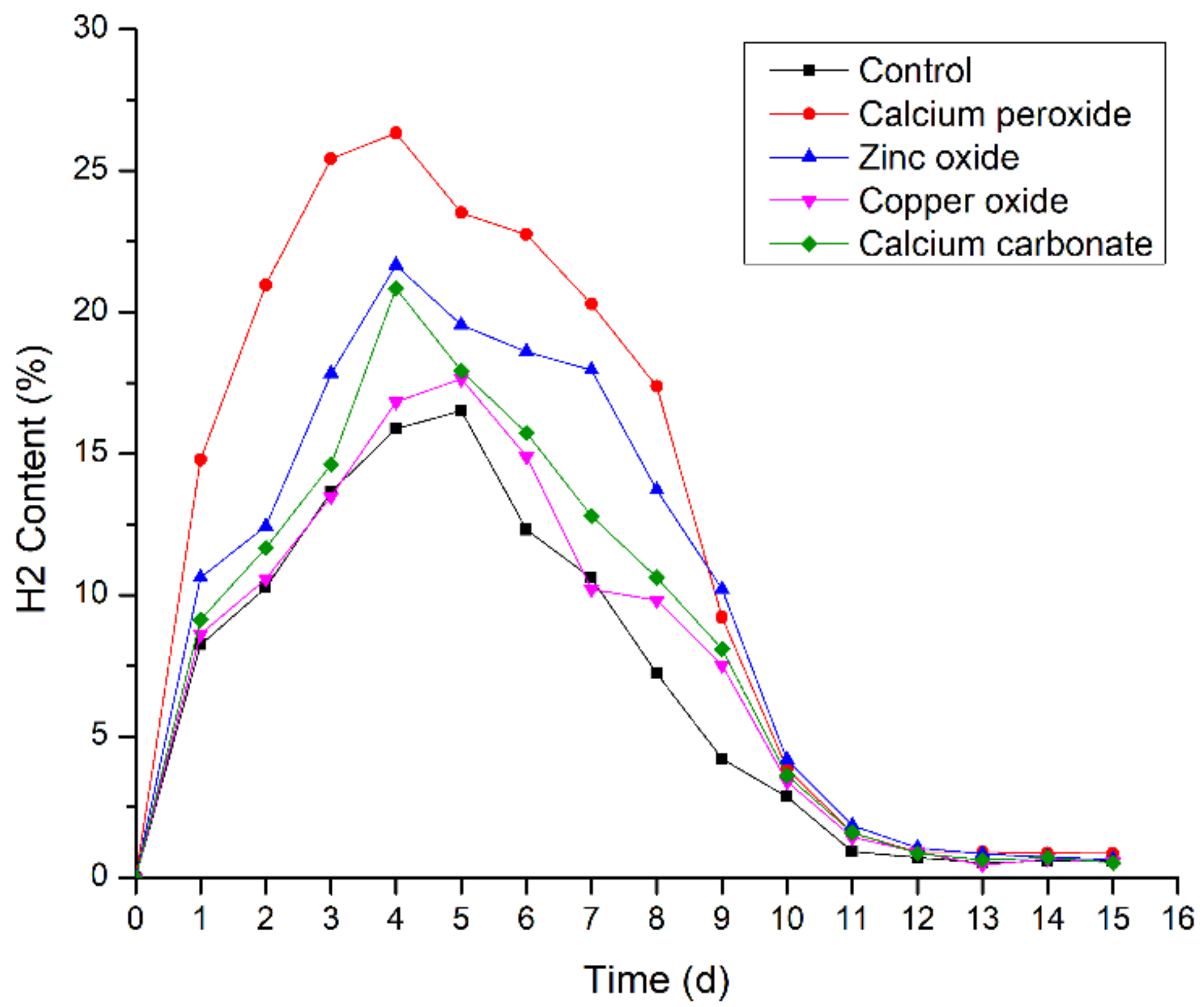

Figure 4

Effect of the additives on hydrogen concentration. 


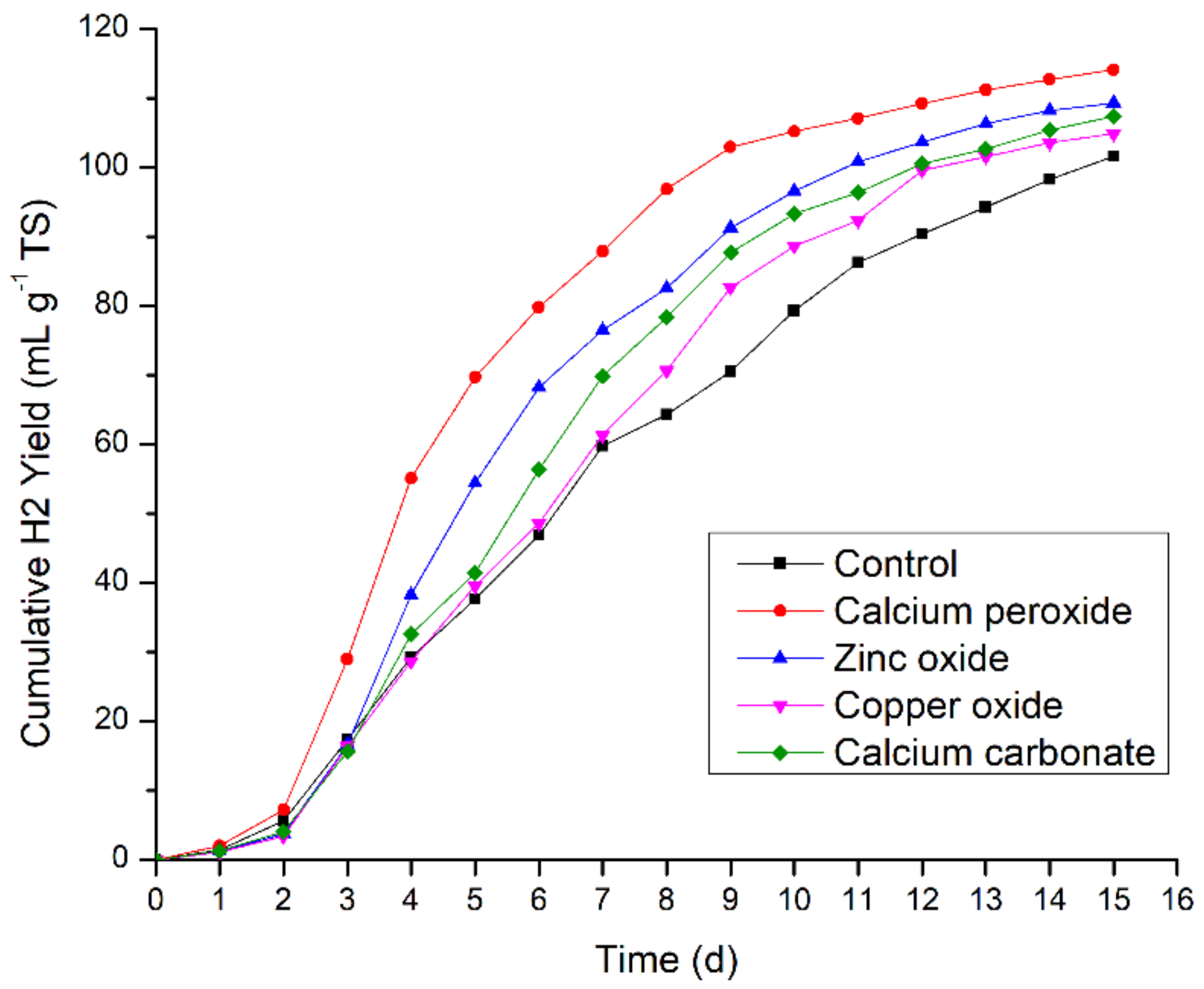

Figure 5

Effect of the additives on cumulative hydrogen yield. 


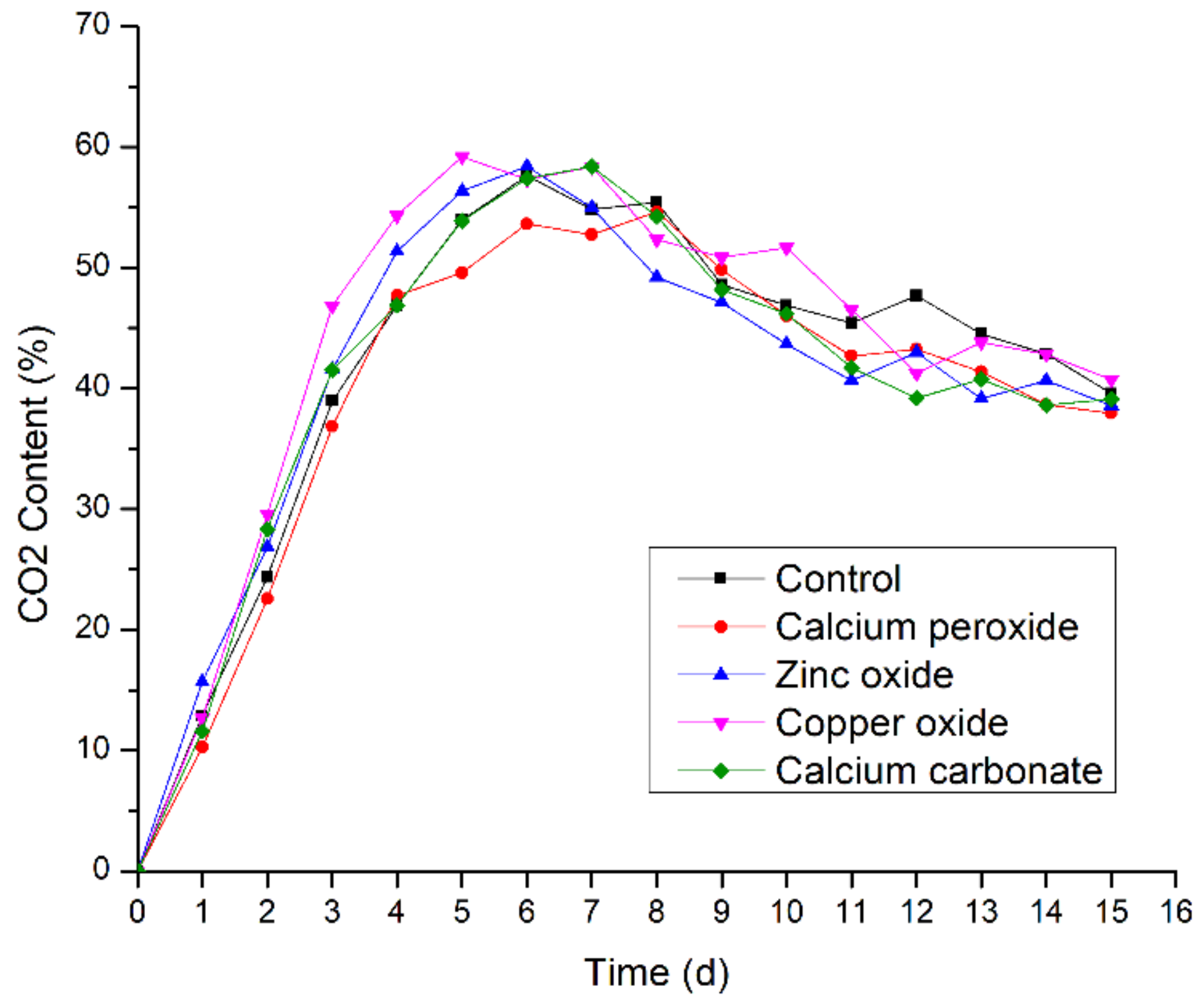

Figure 6

Effect of the additives on carbon dioxide concentration. 


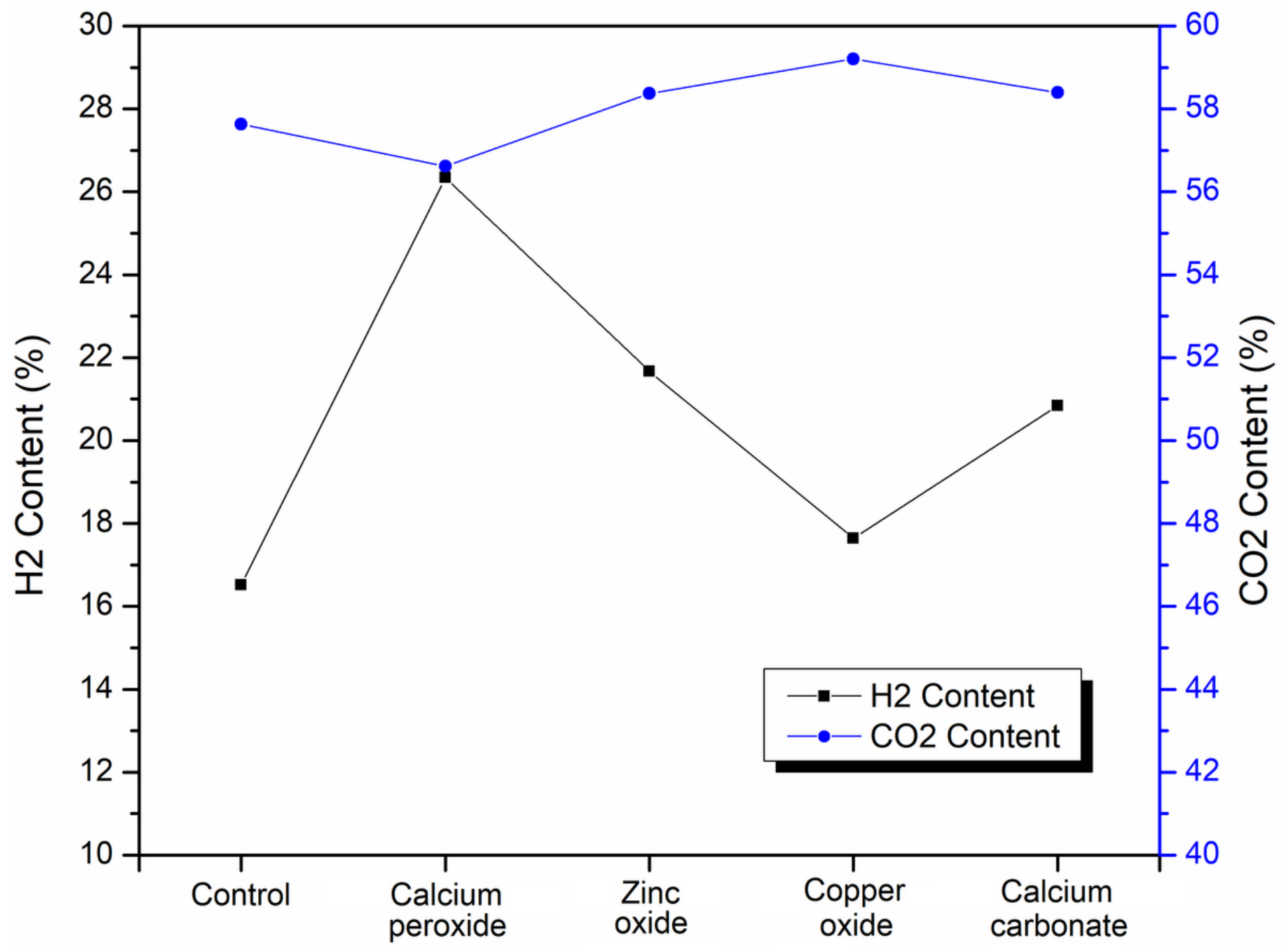

Figure 7

Comparison of hydrogen and carbon dioxide concentration. 


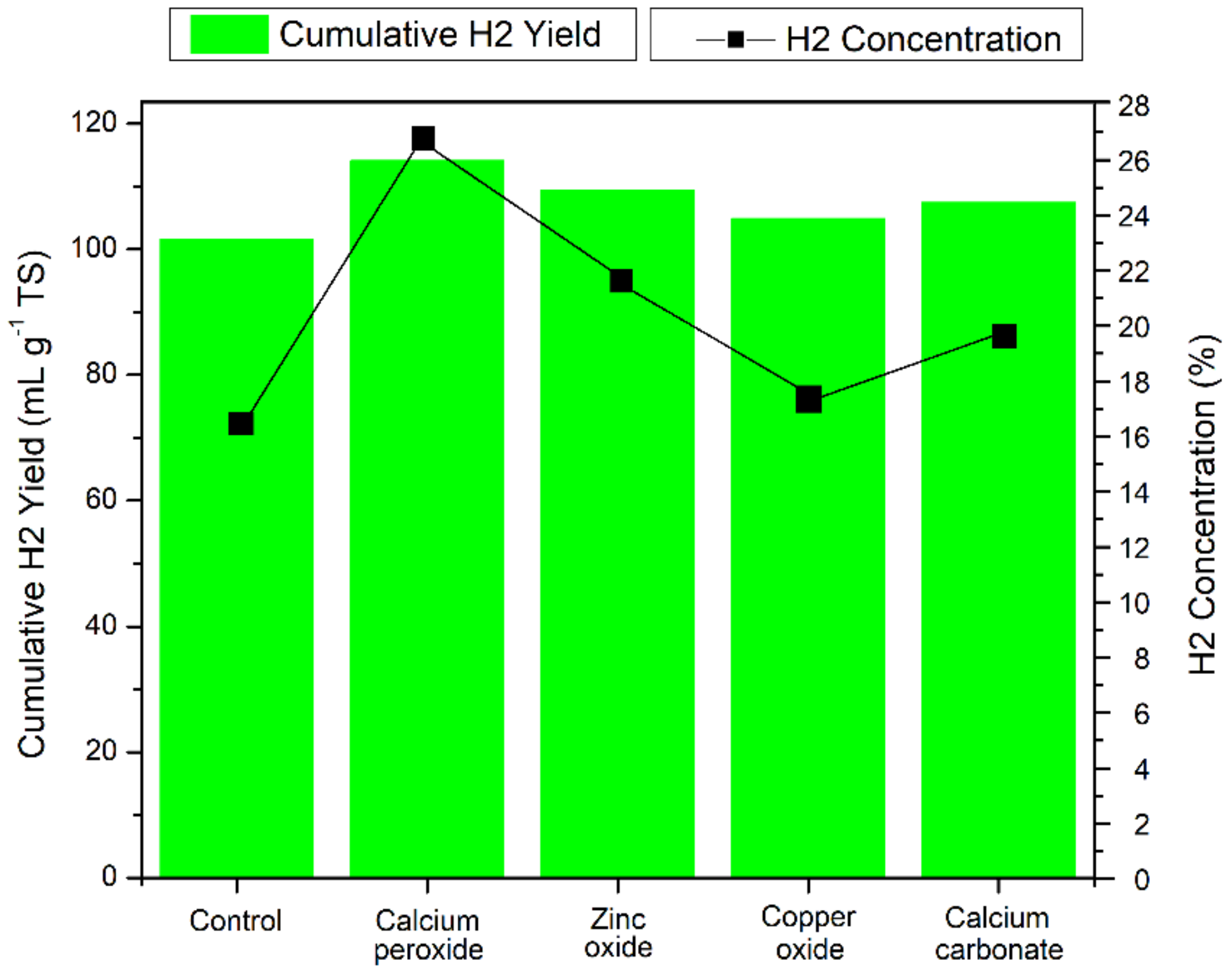

Figure 8

Effect of the additives on hydrogen production. 